Brit. F. industr. Med., 1967, 24, 73

\title{
Miscellanea
}

\section{Mercury Poisoning and Its Treatment with N-acetyl-D, L-Penicillamine}

\author{
V. PARAMESHVARA \\ From the General Hospital, Birmingham ${ }^{1}$
}

Two cases of chronic inorganic mercury poisoning of moderately rapid onset are described. Although exposure was the same in the two patients, the mercurial poisoning affected chiefly the kidneys in one and the gums in the other. Mercurialentis and corneal opacities were seen after short exposure to the metal.

One case was treated successfully with $\mathrm{N}$-acetyl-D, L-penicillamine. No toxic effects were observed and this is suggested as the treatment of choice for mercury poisoning.

Mercury poisoning is still a hazard in industry. The figures for notified cases have scarcely altered since 1899 with a maximum of 18 in a year and an average of seven and eight between 1899 and 1931 (Legge, 1934). Hunter (1962) states that since 1920 less than five cases have been notified annually, but notification does not necessarily represent the actual incidence.

Until recently treatment was largely empirical and of doubtful value (Hunter, 1962; Bell, Gilliland, and Dunn, 1955) but the discovery that N-acetyl-D, L-penicillamine could be used in laboratory animals as a non-toxic chelating agent in mercurialism encouraged Smith and Miller (1961) to prescribe the drug for a patient with chronic inorganic mercury poisoning. The present report confirms the efficacy of this form of treatment.

\section{Process}

The exposure to mercury vapour occurred in the control room of an external electric display sign which, through the selective lighting of bulbs, gave the appearance of illuminated words passing across a screen. The electric contacts for illuminating the bulbs were made by mercury through holes punched out in a paper strip in a sequence to produce the required message. The control room in whose external wall there were two extraction fans, but no window or inlet for fresh air, had a floor area of

\footnotetext{
Present address: No. 27, Shanthi Road, Shanthi Nagar, Bangalore 25, South India.

Received for publication March 15, 1966.
}

I70 sq. ft. (15.7 m. $\left.{ }^{2}\right)$ and a height of $8 \mathrm{ft} .(2 \cdot 4 \mathrm{~m}$.). There was exposure to mercury vapour from the surface of two mercury baths and the frequent spillages off the paper strip and there was also exposure from cleaning and filtering the mercury with resultant further spillages.

Two men were employed and worked alone for one or other of the two shifts in the day, supervising the mechanism and preparing with a press the patterns on the paper strip to transmit news or advertisements.

\section{Case Reports}

Case I C.B. aged 58, who was referred by his family doctor on 1o April, 1965, first developed symptoms at the end of August, 1964, three months after starting work. He complained of lack of energy, irritability, and depression. By the end of December, 1964, he noticed swelling of the ankles. This gradually spread up the legs to the thighs. On questioning he admitted that his voice was hoarse, that he had a metallic taste and that his hands were stiff when writing. He smoked 20 cigarettes a day and drank alcohol occasionally.

He was intelligent and co-operative, pale and poorly nourished, weighing II st. Io $\mathrm{lb}$. (74.3 kg.). He had ascites and generalized pitting oedema extending as high as the abdominal wall. The finger nails were brittle and his voice hoarse. There was a coarse irregular tremor of the outstretched hands but his handwriting was not affected.

Slit lamp examination revealed the presence of mercurialentis and corneal opacities in both eyes. The cornea showed fine, glistening, particulate, centrally placed deposits in the stroma and the periphery was clear. The lens showed a grey line in the subepithelial layer. This was grey with a slight brownish tinge. The 
anterior nuclear layer also showed a fine grey granular mottling. Laryngeal examination was normal.

Investigations Urine: Protein $840 \mathrm{mg} / \mathrm{I} 00 \mathrm{ml}$. (I4.5 g. daily); urea I,040 mg./100 ml.; sodium $94 \mathrm{mEq}$./litre; potassium $27 \mathrm{mEq}$./litre; creatinine clearance $60 \mathrm{ml} . / \mathrm{min}$.; mercury $780 \mu \mathrm{g}$./litre.

Stool: Faecal fat excretion 3.6 to $5.8 \mathrm{~g}$./day.

Blood: Red blood corpuscles $4,400,000 / \mathrm{mm}^{3}$; haemoglobin $13.4 \mathrm{~g}$. $/ 100 \mathrm{ml}$; white blood cells $5,300 / \mathrm{mm}^{3}$, differential counts normal; platelets $246,000 / \mathrm{mm}^{3}$; packed cell volume $39 \%$; mean corpuscular volume $89 \mathrm{cu}$. microns; mean corpuscular haemoglobin concentration $34.5 \%$, red cell fragility normal; no L.E. cells demonstrated.

Serum urea and electrolytes: Serum urea $40 \mathrm{mg}$./100 $\mathrm{ml}$; sodium $137 \mathrm{mEq}$./litre; potassium 4.9 mEq./litre; chloride $108 \mathrm{mEq}$./litre.

Serum protein: Total proteins $4.2 \mathrm{~g} / 100 \mathrm{ml}$; albumin $1.0 \mathrm{~g} . / 100 \mathrm{ml}$. and globulin $3.2 \mathrm{~g} . / 100 \mathrm{ml}$. Electrophoresis showed reduced albumin and gamma globulin levels and an increased alpha II globulin level.

Serum iron $63 \mu \mathrm{g} . / 100 \mathrm{ml}$.; serum calcium $7.7 \mathrm{mg}$. $/$ I00 ml.; phosphorus $3.6 \mathrm{mg}$. $/ 100 \mathrm{ml}$.; serum $\mathbf{B}_{12}$ I88 $\mu \mu \mathrm{g} . / \mathrm{ml}$.; $p \mathrm{H} 7.32 ; \mathrm{PCO}_{2} 47.2 \mathrm{~mm}$. Hg; $\mathrm{HCO}_{3}$ (standard bicarb.) $22.0 \mathrm{mEq}$./litre; serum cholesterol $676 \mathrm{mg} . / 100 \mathrm{ml}$. Radiograph of chest and skull normal. Excretion pyelogram normal.

E.E.G.: This showed a mild dysrhythmic record.

Treatment N-acetyl-D, L-penicillamine (250 $\mathrm{mg}$. four times a day) was given in three nine-day courses with an interval of nine days between each course. Urinary protein and mercurial excretion were estimated throughout the period of treatment. Each course of treatment sharply increased the amount of mercury excreted, but the concentration fell on each successive occasion. After the third course of penicillamine therapy, the daily excretion of mercury was less than is $\mu \mathrm{g}$. and the urinary protein content was $7.5 \mathrm{~g}$. per day. The patient was put on a protein-rich diet and his clinical condition markedly improved. His voice recovered dramatically and the tremor disappeared. A rise in the level of serum albumin from $\mathrm{I} \cdot 0$ to $\mathrm{r} \cdot 8 \mathrm{~g}$. $/ 100 \mathrm{ml}$. was associated with a steady reduction in body weight and oedema.

Case 2 F.H. aged 50 first developed symptoms four months after being engaged as an operator. He stated that his teeth became so loose that the dentist decided that a dental clearance was desirable. Extraction was completed during November, 1964. He is now wearing dentures but complains that his gums are constantly sore. Routine physical examination revealed no abnormalities.

Dental examination showed gingival hypertrophy and areas of dark pigmentation of the gums. Histological examination revealed the deposits of mercury sulphide in the alveolar epithelium (Fig. I).

Examination of the eyes by slit lamp showed bilateral

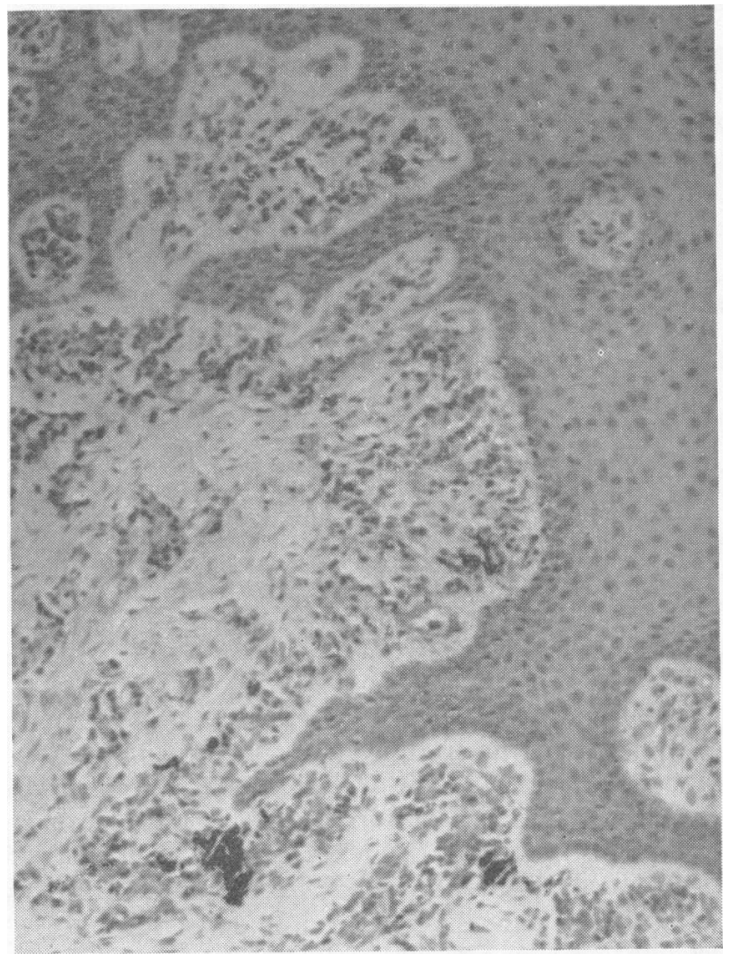

FIG. I. Case 2. Section of alveolar epithelium showing deposits of mercury sulphide.

mercurialentis and corneal bands. The changes were similar to those of case $\mathrm{I}$.

Investigations Urine: Protein $150 \mathrm{mg} / 24$ hours; mercury excretion $550 \mu \mathrm{g} . / 1$; creatinine clearance $124 \mathrm{ml}$./minute.

Blood: Red blood corpuscles $4,500,000 / \mathrm{mm}^{3}$; white blood corpuscles $4,600 / \mathrm{mm}^{3}$; differential count normal; E.S.R. (Westergren) $8 \mathrm{~mm}$./hour; packed cell volume $42.5 \%$.

Serum urea and electrolytes: Urea $30 \mathrm{mg} / \mathrm{I} 00 \mathrm{ml}$; sodium $136 \mathrm{mEq}$./litre; potassium 4. I mEq./litre; chlorides $102 \mathrm{mEq}$./litre; serum cholesterol $298 \mathrm{mg}$./100 $\mathrm{ml}$.

Serum proteins: Total proteins $7.5 \mathrm{~g} . / 100 \mathrm{ml}$; albumin $4.8 \mathrm{~g}$. $/ 100 \mathrm{ml}$. and globulin $2.7 \mathrm{~g} . / 100 \mathrm{ml}$.

E.E.G.: Normal.

\section{Discussion}

Poisoning from metallic mercury occurs in industry, in laboratories, and occasionally as a result of therapeutic use. Although the metal can be absorbed through unbroken skin or mucous membranes, industrial poisoning normally occurs from absorption through the respiratory tract. Mercury 
vaporizes even at room temperature (Bidstrup, 1964).

In this control room inadequate air extraction, with almost complete lack of ventilation, together with spillage of mercury would produce high levels of mercury in the air. The concentration of mercury in air was not measured but estimations reported by Butterworth (1965, personal communication) in a control room where a similar process was carried out with better ventilation gave levels exceeding $0.8 \mathrm{mg} . / \mathrm{m} .^{3}$, eight times more than the maximum allowable concentration (Ministry of Labour, I965). Mastromatteo ( 1965 ) found a concentration of 0.7 to $0.9 \mathrm{mg} . / \mathrm{m} .^{3}$ in the control room of a similar process in which one worker developed mercurialism after two months' exposure.

Both patients developed symptoms within a few months of exposure. In case I the chief damage was renal, resulting in the nephrotic syndrome; in case 2 the teeth and gums were most obviously affected and renal damage was insignificant. Surprisingly, neurological manifestations occurred only in case I and these were mild.

Although both patients had symptoms of mercurialism their mercury excretion was not high, 780 and $550 \mu \mathrm{g}$./1. respectively. These may be compared with findings in 50 mercury workers who showed no signs of mercurialism but 17 of whom were excreting more than $1,000 \mu \mathrm{g}$. $/ 1$. with a maximum of 4,200 $\mu \mathrm{g}$./1. in one worker (Kipling, 1965).
Case I was willing to be admitted to hospital but case 2 refused any treatment. The results of a course of treatment with $\mathrm{N}$-acetyl-D, L-penicillamine given to case $\mathbf{I}$ are illustrated in Figure 2.

Both men developed bilateral mercurialentis and opacities in the corneae within a few months of exposure. Burn (1962) showed that a greyish granular deposit occurs on the anterior surface of the lens within a year or two of exposure to mercury fumes. Kazantzis (1965) described the development of mercurialentis in a switch repairer after one year's exposure to mercury vapour. Abrams (1963) has shown that mercurialentis may appear after three years' use of eye drops containing a mercurial antiseptic. He has estimated that in this period I mg. mercury from the antiseptic would have been applied to the eye. It is of interest that the two workers in the better ventilated control room, who suffered no symptoms of mercurialism, showed no evidence of mercurialentis (Tombleson, 1965personal communication). It seems probable that mercury poisoning from the inhalation of vapour should not be diagnosed in the absence of mercurialentis.

The value of close co-operation between the public health services, the factory inspectorate, the family doctor, and the various specialist departments of the hospital service is well demonstrated by our experience with these patients. Dr. E. L. M. Millar, Medical Officer of Health, has been most helpful throughout, and

FIG. 2. Case I. Mercury excretion in urine.

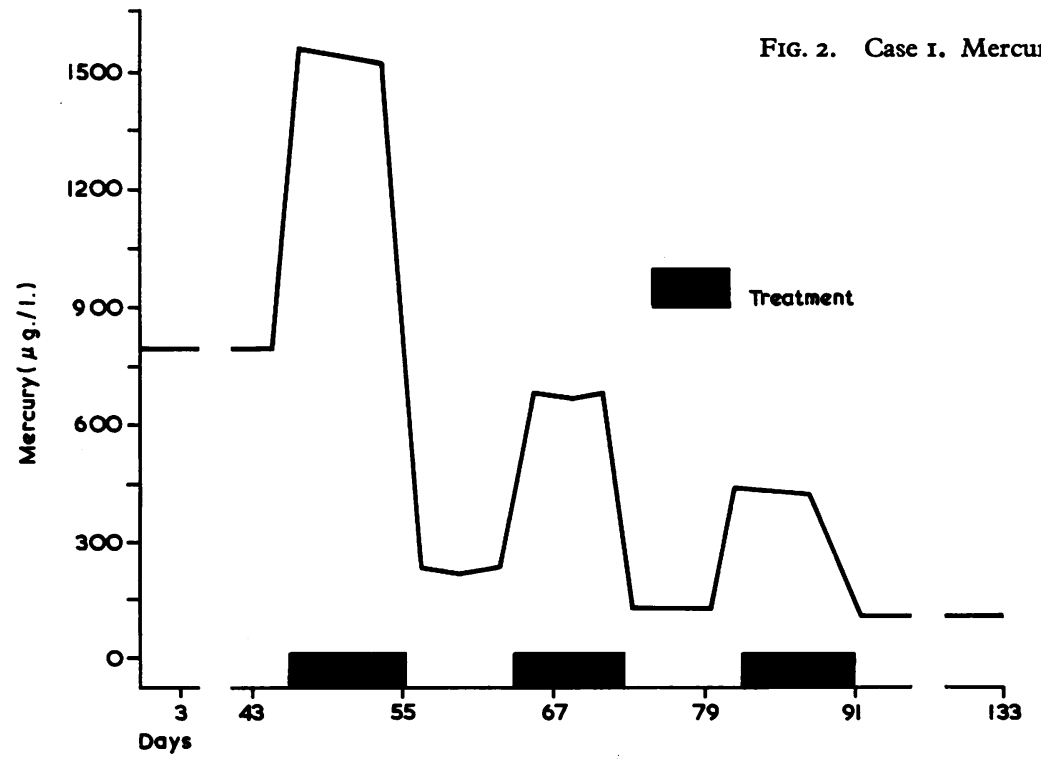


I am indebted to Mr. John Graham and Mr. F. C. Schonbeck, Public Health Inspectors, for bringing this process to our notice. Dr. M. D. Kipling, H.M. Medical Inspector of Factories, has made valuable suggestions about the management of the patients and the writing of this report.

I am also grateful to Mr. L. P. Jameson Evans for his ophthalmological examination, to $\mathrm{Mr}$. R. W. $\mathrm{H}$. Tavenner for the dental examination, to Mr. G. A. Dalton for laryngeal examination, to Dr. A. Butterworth and Dr. J. B. L. Tombleson for information, and to Dr. G. H. Jeavons. Dr. J. D. Blainey, consultant physician to the hospital, and Dr. R. Gaddie, consultant biochemist, have been most generous with their help. I am greatly indebted to Dr. C. G. Parsons for his encouragement and advice.

The N-acetyl-D, L-penicillamine was supplied by the Distillers Company Ltd.

\section{REFERENCES}

Abrams, J. D. (1963). Trans. ophthal. soc. U.K., 83, 263. Bell, R. F., Gilliland, J. C., and Dunn, W. C. (1955). Arch. industr. Hlth, 11, $23 \mathrm{I}$.

Bidstrup, P. L. (1964). Toxicity of Mercury and its Compounds, p. 28. Elsevier, Amsterdam.

Burn, R. A. (1962). Proc. roy. Soc. Med., 55, 322.

Hunter, D. (1962). The Diseases of Occupations, 3rd ed., pp. 285, 299. English Universities Press, London.

Kazantzis, G. (1965). Ann. occup. Hyg., 8, 65.

Kipling, M. D. (1965). Ibid., 8, 8I.

Legge, T. M. (I934). Industrial Maladies, p. 9. Oxford University Press, London.

Mastromatteo, E. (1965). F. occup. Med., 7, 502.

Ministry of Labour (1965). Dust and Fumes in Factory Atmospheres, Safety, Health and Welfare, No. 8. H.M.S.O., London.

Smith, A. D. M., and Miller, J. W. (196I). Lancet, r, 640.

\section{The October (1966) Issue}

The October (1966) issue contains the following papers:-

Trichlorethylene: A Review G. F. SMITH

Urinary Screening Tests to Detect Excessive Lead Absorption Part I and Part II R. W. ElLIS

Studies in Lead Poisoning. S. Selander, K. Cramér, and L. Hallberg

Acute Cadmium Fume Poisoning: Five Cases with one Death from Renal Necrosis. D. C.

Beton, G. S. ANDRews, H. J. Davies, L. Howells, and G. F. SMith

Acute Toxicity and Skin Irritant Properties of Sulfolane. V. K. H. Brown, L. W. FerRIGAN, and D. E. STEVENSON

Chronic Toxicity of Aluminium in Rats and Mice and its Effects on Phosphorus Metabolism. R. ONDREIČKA, E. GINTER, and J. KORTUS

Hypocalcaemia in Experimental Cadmium Poisoning. A. KENNEDY

Acute Intoxication from Antimony Trichloride. P. J. TAYLOR

Miscellanea

The Appointed Factory Doctor Service: Just a Face-lift or a New Breed ? R. F. L. LogAN

\section{Book Reviews}

Index

A number of copies are still available and may be obtained from the Publishing Manager, British Medical Association, Tavistock Square, W.C.I, price $18 s .6 d$. 
restricted traditional sense, but he also finds the space to deal with the history of lunacy, the maternal and child welfare service, the care of neglected children, and geriatrics. One criticism may, however, be made. Few people have made a greater contribution to research in the history of public health than the author, and it is therefore all the more disappointing to find that a number of important recent books are not listed in the bibliography, e.g., L. F. Hirst, The Conquest of Plague (1953); R. A. Lewis, Edwin Chadwick and the Public Health Movement, I832-1854 (1952); Dr. Kathleen Jones, Lunacy, Law and Conscience, I744-1845 (1955); and J. L. and Barbara Hammond, Fames Stansfeld: a Victorian champion of Sex Equality (1932).

W. H. Chaloner

An Introduction to Social Medicine. By Thomas McKeown and C. R. Lowe. (Pp. 327; 50s.) Oxford: Blackwell Scientific Publications. 1966.

Medical education is being changed from the largely vocational training of the past into an education concerned with the opening up and development of the student's mind. In this light, one approaches a new textbook for students to see how it succeeds in this task.

The list of contents presenting the subject matter bodes well. Here is that clear and logical arrangement, at once so obvious when it is set out, but which has eluded so many others before. Part I deals with the 'problems' which are the medical needs of society. Part II goes on to discuss the methods which may be used to tackle these problems: Control of Inheritance and Eugenics; Personal Measures for the Control of Environment; Public Measures for the Control of Environment. Finally, Part III deals with the Services which have been developed in this country to put these methods into effect. Whilst this arrangement of the book is compelling in its logic, it can lead to repetition, a fault which could be corrected in subsequent editions.

The industrial medical officer will see his field fairly presented in the full context of medical needs and medical services, although he may be a little disappointed in some of the detail. The industrial disease responsible for more lost time than any other is dealt with in half a sentence: 'Finally .... and in dirty occupations lack of proper washing facilities increases the risk of dermatitis.' In this country we have a proud and rightly envied tradition of factory inspection. To write: 'In particular, although legislation is concerned for the most part only with minimum standards, the machinery devised to operate it is inadequate to ensure that even minimum standards are always observed', hardly does justice and might create the wrong impression, as any review of our history of factory inspection will show.

However, the book as a whole is well presented and the points are clearly argued. It is to be hoped that in subsequent editions the authors will be able to clear up some of the finer points of detail.

W. R. LEE

Occupational and Environmental Cancers of the Respiratory System. By W. C. Hueper. (Pp. 214; 48 figs; DM 34.) Berlin: Springer-Verlag. 1966.
The publication of this third volume of a series of monographs on recent results in cancer research is timely. It gives a comprehensive presentation of the epidemiology and pathology of occupational cancers of the respiratory system and of experimental research on them.

There are short preliminary sections dealing with non-specific industrial irritants, with the general epidemiology of specific industrial respiratory carcinogens and with the role of smoking in the production of cancers in the industrial population.

The main part of the book deals fully with specific cancers arranged alphabetically under causative agent and includes an outline of manufacturing processes. There is a very brief section on prevention and treatment. The reference list includes over 1,500 entries but unfortunately there are few after 1964. In some of the tables, too, one could have wished for figures more up-to-date.

In spite of this criticism there is no doubt that this massive collection of data will be of value to anyone interested in improving the industrial environment or dealing with those exposed to it, and it is a welcome addition to the literature on the subject.

C. B. MCKERROW

\section{NOTICES}

\section{International Social Security Association}

The Fifth World Congress on the Prevention of Occupational Accidents and Diseases will be held in Zagreb, July 2-9, 1967. The Congress will be held on the premises of the Zagreb Fair.

For further information write to: Dr. D. Djordević, Secretary-General, Fifth World Congress on the Prevention of Occupational Accidents and Diseases, P.B. 15, Zagreb III, Yugoslavia.

On July IO and II, I967 and in the framework of the Fifth World Congress will be held the Fourth International Colloquy on the Prevention of Occupational Risks in Building and Public Works.

\section{Royal College of Advanced Technology, Salford}

A one-day symposium on the Collection and Handling of Medical Data will be held at the Royal College of Advanced Technology, Salford on Saturday, May 6, I967, at I0.00 a.m.

The fee for the symposium is four guineas which includes morning coffee, buffet lunch, and afternoon tea. Applications for admission should be made to: Professor J. H. Calderwood, 'The Collection and Handling of Medical Data,' c/o Postgraduate Medical Institute, Salford H.M.C. Office, Fairhope Avenue, Salford, 6.

The fee should not be sent with the application; it will be requested later when an enrolment form is sent.

\section{CORRECTION}

In the paper by V. Parameshvara on Mercury Poisoning and Its Treatment (vol. 24, p. 73) the drug used was $\mathrm{N}$-acetyl-D-penicillamine. 